\title{
LABOR MIGRATION: CURRENT AND PERSPECTIVE CHALLENGES FOR UKRAINE
}

\author{
Heorhiy CHEREVKO ${ }^{*}$ \\ Institute of Economics and Finance, University of Rzeszów, Rzeszów, Poland
}

Received 29 March 2021; accepted 13 September 2021; first published online 28 December 2021

\begin{abstract}
The main purpose of this study was to analyze the labor resources migration phenomenon from Ukraine in the context of theoretical basics of it generalization and against the background of its evolution and world trends, to identify its specific features, real consequences and possible perspectives regarding the regulation possibility taking into account the specifics of the nature and structure of this phenomenon in this country. The research methodology is formed on the basis of the classic economic theory of migration in combination with the behavioral approach and the interpretation of human as homo oeconomicus. Methods were used in the research process: dialectical, historical and semantic analysis, method of theoretical generalization and scientific abstraction, induction and deduction, monographic, graphic, statistical and analytical. The main findings are related to the detection of the tendency to increase the scale of labor migration from Ukraine even under conditions of pandemic, the identification of threats and harms connected with this phenomenon. Substantiated recommendations for eliminating the threats and harms of international labor migration from Ukraine may have practical applications. The originality of the article is determined by its timeliness and by diversified set of used sources of information, what together forms its value as well.
\end{abstract}

Keywords: international migration, migration, theories, factors, Ukraine, pandemic, perspectives, regulation.

JEL Classification: F22, J11, J61.

\section{Introduction}

Globalization has created the conditions for the free movement of labor among countries and continents, and the borders closed through COVID-19 will inevitably open. Therefore, it is obvious the constant relevance of the study of migration as some of the most important and pressing global issues of our time in the context of identifying its essence, causes, scale, trends and real consequences, justification of possible ways to reduce its volume and negative consequences under specific conditions and taking into account their local specific features.

*Corresponding author. E-mail: gcherevko@ukr.net

Copyright (c) 2021 The Author(s). Published by Vilnius Gediminas Technical University

This is an Open Access article distributed under the terms of the Creative Commons Attribution License (http://creativecommons. org/licenses/by/4.0/), which permits unrestricted use, distribution, and reproduction in any medium, provided the original author and source are credited. 
Exactly labor resources migration is especially relevant today for Ukraine because it has a large scale and seriously affects the economic and social development of the whole country. The working hypothesis in these studies was the assumption that the scale of labor migration from Ukraine due to the current economic situation is not decreasing, but on the contrary increasing, despite the risk of death due to COVID 19, and that the negative consequences for Ukraine may become pathological as a result of this process if regulatory measures will be not taken. Therefore, the purpose of this article is to present the main results of the study of labor migration from Ukraine against the background of similar processes in the world, to highlight its features in this country and to anticipate some possible scenarios and consequences in the near future in reliance on the theoretical basis of migration processes and also - to suggest the basic conditions of realization of the main ways of these processes regulation.

\section{Theoretical conceptions of migration}

It is obvious that the complexity of migration processes, especially at the international level, is so high that there is no reason to talk about the possibility of a single theory of migration formulating (Arango, 2000). And it would be so general that its use to clarify specific problems would be impossible (Brzozowski, 2011). Most migration theories, which are considered "classic", originated in the West (Ivahnjuk, 2015). All theoretical concepts of migration today are considered in terms of groups - the theories of domestic and international migration; theories of migration as a factor of change in the environment; classical and systemic theories of migration; micro-level theories (behavioral) and macro-level; disciplinary theories - economic, sociological and geographical (Janicki, 2007).

Since the basis of human life is objectively the sphere of economics, it is logically to consider, that among all theories of migration just economic theories are the most important, which began to take shape relatively actively in the early of twentieth century. One of the first effective researchers of this phenomenon was John Hicks, who argued, that differences in economic benefits, especially in wage levels, were the main reason for migration (Hicks, 1932). Geographer E.G. Ravenstein identified in the nineteenth century that the main cause of migration is a person's natural desire to improve their financial situation, and outlined a series of "laws of migration" (Ravenstein, 1885; Corbett, 2003). From those, the last is the most important today, namely the seventh - no factor of migration has such force as the natural desire of man to live in better material conditions (Brzozowski, 2011). That is, economic motives are the main cause of migration. His paper was published at the time when great variety of people were on the move, and it soon became clear that the phenomenon is much more complex than geographers could describe (Nestorowicz \& Anacka, 2019).

The first most developed classical theory of migration represents migration as a result of flows of workers in the labor market as a means of achieving balance in it (Olsson, 1965). Arthur Lewis is considered to be a pioneer of the classical theory of migration with his most fundamental work on the necessity of the existence of migration in economically different territories (Lewis, 1954). He laid the theoretical foundations for the existence of a dual economy during its development and introduced the concept of the so-called balance of utility - the migration process will stop on its own when wage conditions in the donor country and in the recipient country are equalized. 
The creators of neoclassical theories try to bring the classical theory of migration closer to real life, according to which migration movements are a compensatory reaction to the difference in wage levels due to the difference in the amount of demand and supply of labor (Todaro, 1976). And M. Todaro replaced the differences in wages with differences in expectations regarding the level of wages. Based on the neoclassical theory of migration, the theory of a new migration economy emerged, where decisions on migration are also determined by financial factors, but the choice is made not by one person but by a group of people, most often - by household (Piche, 2013). The purpose of household members is identified not as income maximization, but as the risk of financial difficulties at different stages of the family development cycle minimizing (Stark, 1991) what, in the ground of things, is the same. And according to R. Mandell, the decisive influence on labor flows has the labor supply of the country and migration is determined by the relative formation of prices of productive factors - capital and labor (Cabańska, 2018). The theory that complements the theory of migration from the side of demand is the so-called dual theory of the labor market of Doeringer and Piore, according to which the economy is always differentiated, not as in Lewis's theory - only in its development phase, and labor demand factor is market segmentation (Doeringer \& Piore, 1971). The dual labor market theory (Piore) analyzes migrations from the sides of demand (employers) and supply (employees) (Kacperska, 2016). According to this theory, citizens of highly developed countries avoid unattractive sectors, but foreigners are readily accepted here (O’Reilly, 2016).

Economic theories of migration do not contradict, but complement each other, distinguishing many factors, which shape the flows of international migrants. The values of these factors vary depending on the very dynamic situation in the world economy and relate to both the reasons why people leave the donor country and the reasons for choosing a particular recipient country. Mostly migration is explained by the behavioral characteristics of man as homo oeconomicus, according to which human moves in space to where his needs will be most satisfied in the closest way to his expectations (Cabańska, 2018). That is, the main reason for human migration is the differentiation in the provision of labor resources in different countries, and, as a consequence, a significant difference in wage levels.

\section{Research methods and sources of information}

The main research methods used during its conduction were: dialectical, historical and content analysis - to study the genesis and evolution of the phenomenon and its theoretical concepts; statistical-analytical - in assessing the scale of the phenomenon; index - in the implementation of quantitative characteristics and identification of trends in the phenomenon of international migration of labor resources and their migration from Ukraine; questionnaire - to confirm the range of root causes of this phenomenon; monograph - in studying the experience of business structures to encourage employees to stay and work in Ukraine; method of theoretical generalization and scientific abstraction - to study the possibilities of regulating the negative trends of migration from Ukraine and the level of readiness of government and business structures to implement them.

The study used methodologies and data from the: United Nations Department of Economic and Social Affairs (UN DESA), the International Organization for Migration 
(IOM UN), Migration Data Portal, employment agency EWL Group, International Labor Organization (ILO UN), Bloomberg, All-Ukrainian Association of International Employment Companies, "Slovo i Dilo" Analytical Portal, Ukrainian Center for Economic Strategy, Center for Economic Statistics of Ukraine, Ministry of Social Policy of Ukraine, German Advisory Group in Ukraine, Ukrainian Labor Force Survey (LFS), Center for Social and Economic Research CASE Ukraine, Sociological group "Rating”, KIIS - Kyiv International Institute of Sociology, NBU, Polish Union of Entrepreneurs and Employers.

\section{Evolution of labor migration from Ukraine}

The entire history of Ukrainian labor migration can be divided into several main so-called "waves", the first of which was the outflow of Ukrainians to Turkey and Western Europe. The beginning of mass migration of Ukrainians dates back to 1877, when the first group of peasants from Western Ukraine came to work in the mines of Pennsylvania, what marked the beginning of the formation of Ukrainian ethnic settlements in the US and in the Canada.

The beginning of mass migration from Ukraine to Latin America dates back to the end of the XIX century. Its second wave falls between the First and Second World Wars and already had a wider socio-class spectrum, qualitatively evolved from a purely labor to the so-called colonial type of migration, the share of intellectuals in the number of migrants increased. The third wave of migration of Ukrainians to these countries regards to the first postwar years.

Before the First World War groups of Ukrainians from western Ukraine settled in Great Britain and Belgium, and seasonal migration of peasants from western Ukrainian lands to Germany (up to 75.000 per year) and to Denmark began. A much larger wave of migration from Ukraine to Germany and Austria of those, who did not recognize Soviet power, occurred in 1919-1920. For 1946-1947 about 25 thousand people left, primarily to England, Belgium, France, Brazil, Venezuela, Australia, Canada.

A new surge in mass labor migration from Ukraine occurred in 2009-2010: the global economic crisis has crippled the financial well-being of Ukrainians (Dmytruk \& Chudayeva, 2018). In Ukraine they are now talking about the "fifth big wave" of migration, which is marked by an overall significant intensity, despite certain temporary environmental constraints, such as COVIT-19. To some extent, the Russian invasion in 2014 and introduction of a visa-free regime of Ukraine with the EU in 2017 gave new scale to these processes.

\section{Dynamics and scale of migration}

According to the World Migration Report 2020 of UN IOM the number of international migrants is estimated to be almost 272 million of a global population of 7.7 bln: 1 in every 30 people (119 mln more than in 1990, when it was $153 \mathrm{mln}$, and over three times the estimated number in 1970, when it was $84 \mathrm{mln}$ ), with nearly two-thirds being labor migrants. This figure remains a very small percentage of the world's population (at 3.5\%) $(2.8 \%$ - in 1995 and 2000, 2.3\% - in 1970), meaning that the vast majority of people globally (96.5\%) are estimated to be residing in the country in which they were born (International Organization for Migration, 2020). 52\% of international migrants were male, and $48 \%$ - female. $74 \%$ 
of all international migrants were of working age (20-64 years) (International Organization for Migration, 2020).

According to the SSSU, 41.9 million people live in Ukraine (including 34.2 million people aged $18-64$, i.e. $82 \%$ ), which is $19 \%$ less than in 1990 and is $0.54 \%$ of the world's population (State Statistic Service of Ukraine [SSSU], 2019). According to Migration Informational Sourse, the total population of Ukraine is 43.9 million people (Migration Policy Institute, 2019). The SSSU estimates the number of ukrainian labor migrants at 1.3 million (SSSU, 2019). That is, in the total number of international migrants, Ukraine accounts for $0.02-0.05 \%$.

According to UN DESA, Ukraine is among the ten countries with the largest number of migrants, which has increased in recent years. According to the data, Ukraine is on the 7th place in the Top 20 origins of the world stock of international migrants) and on the 4 place in Europe (and in terms of the number of migrants - second only to Russia) (International Organization for Migration, 2018). In 2019, almost 5 million Ukrainians lived outside Ukraine (compared to almost 7 million in 1990), and the total number of migrants from Ukraine was 5.9 million. The percentage of migrants from the total population of Ukraine in 1990 was $13.4 \%$, in $2019-11.3 \%$. The share of women among Ukrainian migrants in 1990 was 57.2\%, and in 2019 - 57\% (Migration Data Portal, 2019), i.e., the gender structure of Ukrainian migrants differs significantly from that in the world. The share of Ukrainian migrants in the age group of 20-64 increased from $69.4 \%$ to $73.2 \%$ (Strelnikov, 2020).

The general trend of international migrant stock (\%) in Ukraine for 1990-2019 looks like in Figure 1.

Figure 1 shows, that international migrant stock as a percentage of the total population in Ukraine from 1990 to 2010 had the gradual downward trend, and since 2010 it turned into the upward trend (Migration Data Portal, 2019). At the same time, in Ukraine, net migration in the 5 years prior to 2019 amounted to only 50 thousand people. The net migration rate in 2010-2015 was 0.2 migrants/1000 population. The forecast for 2020 was 2.3 migrants/1000 population (Migration Data Portal, 2019)

Data from the SSSU make it possible to estimate, that $69 \%$ of international labor migrants in the migration module of the labor force survey are from the west of Ukraine, although only $27 \%$ of the country's population lives in this region. The west of the country ( 8 western regions of the country are considered as such) was and remains a relatively poor region,

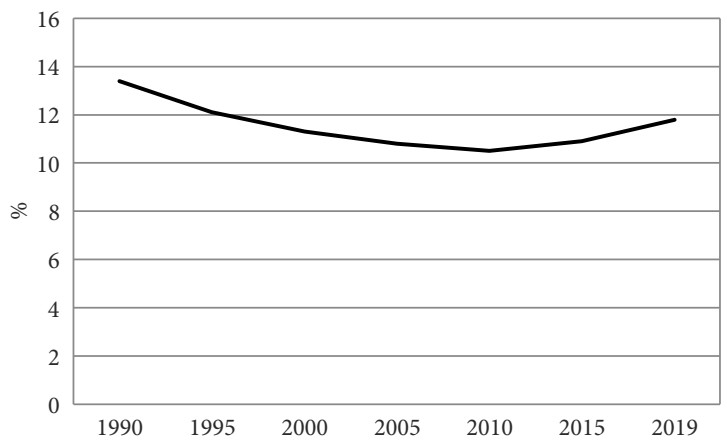

Figure 1. The dynamics of the international migrant stock (\%) in Ukraine (Migration Data Portal, 2019) 
producing only $16 \%$ of Ukraine's GDP. Only about a third of Ukrainians live in rural areas. Migration rates here are twice as high as in urban areas. 61\% of labor migrants in 2019 are men. In the countries of employment, according to the same data sources, the only exception is Italy, where $71 \%$ of labor migrants from Ukraine are women who are engaged in the field of care services in Italian families. $41 \%$ of labor migrants are under the age of 35, compared to $34 \%$ of the total population. In Poland, $47 \%$ of Ukrainian labor migrants are under 35 years of age. The share of migrants with secondary education is $65 \%$, with basic higher or incomplete higher education - 15\%, with completed higher education - 15\%, 5\% - with primary or incomplete secondary education. The share of migrants from Ukraine with higher education (30.5\%) is lower than among the working age population (45\%). The main areas of employment of Ukrainian migrants abroad - home care - 18\%, 9\% - wholesale and retail trade, $11 \%$ - agriculture, $4 \%$ - industry, $4 \%$ - hotel and restaurant business, $4 \%$ - transport sector, $46 \%$ - construction (SSSU, 2019).

The analytical portal Slovo i Dilo claims that between 7 and 9 million Ukrainians take part in the migration process every year, and in 20183.2 million people worked abroad on a permanent basis, which amounted to $17.8 \%$ of able-bodied Ukrainians (Slovo i dilo, 2018). This is confirmed by data from the Ministry of Social Policy of Ukraine and IMF estimates (International Monetary Fund [IMF], 2019). In particular, in the report of the IMF, published in January 2019, the number of labor migrants from Ukraine is estimated at 2-3 million people (IMF, 2019). According to the Institute of Demography of the National Academy of Sciences of Ukraine, the number of Ukrainian labor migrants is 2.3 million, to the Kyiv School of Economics - 2.5 million (Tyshchuk, 2018). These estimates also largely coincide with recent surveys by the Center of Economic Statistics of Ukraine, where the average number of Ukrainian labor migrants is estimated at 2.6 million (Zaha \& Luke, 2020). And according to the Center for Economic Strategies, in 2001-2018, about 6 million citizens left Ukraine, of which about 4 million are earners (about 16\% of the total number of Ukrainians of working age) (Radchuk, 2018). In 2012-2017, migration to Russia decreased by at least a third, and to Poland - tripled to half a million. Three of four Ukrainian labor migrants in 2017 worked in EU countries (Zaha \& Luke, 2020).

According to the Polish Foreign Ministry, 2 million Ukrainians work in this country (Garmash, 2018). A study of the National Bank of Poland indicates that in 2017-2018, in this country 200.000 Ukrainian labor migrants arrived every year (Ponzel, 2020). According to Central Statistical Office of the Republic of Poland, as of December 2019, there were more than 1.35 million Ukrainians in Poland (Kaźmierczak, 2020). The rapid increase in the number of migrants to Poland can be attributed to the dynamic growth of the Polish economy and the high number of job vacancies, but also to visa liberalisation (since 2017) and legislative changes, facilitating the employment of Ukrainians (Pieńkowski, 2020). However, labor migration to Poland from Ukraine is also the most circular, mainly due to the close distance.

Labor migration from Ukraine is caused, first of all, by economic problems inside the country, as a result of which living and working conditions and the level of its remuneration do not satisfy the demands of working Ukrainians. Ukraine is the poorest country in Europe in terms of GDP per capita (Dubrovskyj, 2018). GDP per capita in Ukraine is $\$ 3095$ per year, against $\$ 10-\$ 11$ thousand on average In the world and $\$ 15.4$ thousand in Poland or 
$\$ 116$ thousand - in Luxembourg (Yasinchuk, 2020). Human Development Index Ranking of Ukraine ( 1 = High; 188 = Low) (UNDP) in 2019 is only 88 (Migration Data Portal, 2019). $80 \%$ of the country's GDP goes to consumption - simply put, it is eaten. And only a maximum of $20 \%$ goes to investment in equipment and development, and the state is considered economically successful if the ratio is quite the opposite (Yasinchuk, 2020). It is clear that in this situation wages can not be high, what encourages people to seek a better life abroad.

The results of questionnaires conducted by the author of the article in the Rzeszow Regional Administration in the period from December 2018 to May 2019 among a fairly homogeneous target direction audience, showed, that among the surveyed Ukrainians, wishing to obtain a temporary residence card in Poland, $78 \%$ called the main purpose of their trip to Poland the earnings searching which they cannot find in Ukraine. 17\% turned out to be students, and only $5 \%$ of them consider returning to Ukraine after graduation as a possible option for their future.

More than half of Ukrainian labor migrants in the EU are employed in work which requires only basic training. $46 \%$ of migrants in Poland, 56\% in Italy and only $21 \%$ in Russia, according to their information, are too highly qualified for the work they perform (Ponzel, 2020). In Poland earners from Ukraine are mainly employed in lower-level positions (72\% of cases) and occupy middle-level positions that require appropriate professional qualifications, in every fifth company in Poland. $4 \%$ of workplaces employ Ukrainians in senior management positions (Trojan, 2019b). According to the sociological group "Rating", 77\% of Ukrainians in Poland perform mainly manual work, $16 \%$ - work in the service sector, $3 \%$ - have intellectual work, and only $1 \%$ work in management positions (Radchuk, 2018). Europeans pay the least for unskilled and low-skilled work, but apparently the wage gap with Western Europe is still large enough to make labor migration worthwhile (Zaha \& Luke, 2020). Probably largely due to the above Ukrainians can count on ever higher salaries in Poland, although they mainly work on lower-level positions, but the potential of Ukrainian immigration is running out and it is necessary to simplify procedures to change the nature of Ukrainian immigration from temporary to permanent (Trojan, 2019b).

Ukrainians continue to go to work in European countries - not so much as before to Poland, but also quite intensively to Germany. The German government has passed a bill significantly facilitating labor migration for Ukrainians. So, Germans and citizens of other EU countries in Germany will no longer have priority when hiring. The Germans will issue a work visa to Ukrainians for six months, even without invitations to work. The list of priority professions includes 62 specialties, both for highly qualified specialists with higher education and for representatives of working professions (Yashchenko, 2018). Therefore, although living in Germany is more expensive than in Poland, the minimum wage in Poland is around $€ 480$, and in Germany - €1500. Poland estimates the possible loss of at least 500.000 potential workers as a result (Yashchenko, 2018).

And according to the Polish Union of Entrepreneurs and Employers, the Polish economy will need another 5 million workers over the next 20 years to maintain its current growth rate. Ukrainians will apply for these positions if Ukrainian business does not increase salaries and the government does not provide decent living conditions (Pyrozhok \& Kornienko, 2018). 


\section{Benefits and harms of international migration from Ukraine}

Labor mobility is cost-effective because it provides optimal resource allocation, thereby generating higher and better productivity and greater welfare (Constant \& Zimmermann, 2017). For example, the contribution of all migrants from Ukraine to Poland's GDP growth is about $11 \%$ (Kapustianskaya, 2020). Working for the economy of other countries, Ukrainians pass the money home to their families. According to the World Bank, the volume of remittances to Ukraine in 2018 amounted to $\$ 14$ billion, which is $19 \%$ more than in 2017 or about $10 \%$ of Ukraine's GDP. This is more than 3 times the volume of the entire IMF loan program, which the Fund approved at the end of 2018 (Vinokurov, 2019) and also three times - all foreign direct investment (Libanova, 2020). Of course, these funds enabled a large part of the population, in particular - of the western regions (and the economy of these tourist regions lost the most from quarantine), to survive the economic troubles. Of course, this stimulates domestic demand, allows trade to develop and contributes to the stabilization of the national currency and the balance of payments of Ukraine with its surplus. So, it is quite unclear the government's attempts to impose some taxes on these transfers - it will only "drive" them into the "gray" zone. According to the CASE Ukraine, it is estimated that the Ukrainian economy would lose about $7 \%$ of its potential without the stimulating effect of migrant transfers. $73 \%$ of remittances are spent on accommodation and $26 \%$ - on consumer goods, and only $3.3 \%$ are used for business development (International Organization for Migration, 2013).

However, exactly migration is the cause of a deep crisis in the labor market and exacerbates depopulation, sharpes the problems of pensions, creates problems of economic development caused by lack of skilled workers. An overview of studies in Organisation for Economic Cooperation and Development (2011) concludes that a $10 \%$ increase in migration leads to a $2 \%$ to $6 \%$ increase in wages (Pieńkowski, 2020). But under conditions of Ukraine it is possible to speak only about existence of the expressed direct influence of money of earners on incomes of their families as any dependence between scales of migration and a salary here actually is not present. Although wages in Ukraine are rising fast, to some extent - due to the constant increase of their minimum level by the government (what in practice is more populist than practical) - the rise in prices outpaces the growth of wages. Under conditions of recession of the Ukrainian economy, just this is the factor of searching the better working conditions and earnings abroad.

Remittances of workers have a dual effect on the Ukrainian economy. The well-being of individual families is indeed growing, but the increase in money supply, without economic development, leads to inflation rising. Even if Ukrainian employers start paying higher wages to keep truly qualified staff, this will reduce the competitiveness of Ukrainian goods, especially those that are exported, and inflation will again "eat" these increases.

In light of the mismatch between migrants' skills and the work they do performed abroad, labor migration of Ukrainians can, at least to some extent, be characterized as a "brain drain", but only to a certain extent, because regardless of the reasons for migration, the -brain drain- occurs only when in the country to which an educated person immigrants, his education is considered to be high (Kaczmarczyk \& Okólski, 2005). At the same time, during the years of independence Ukraine has lost about a third of its scientific potential and continues to lose it - only for 1991-2014. 660 doctors of sciences and 1500 candidates 
of sciences (PhD) left Ukraine (Ivantsyk, 2020), which practically means a significant loss of intellectual potential of the country. The literature shows that, in many countries, prospects for migration stimulate education efforts as they provide additional incentives to complete higher education (Piękowski, 2020). In Ukraine, this pattern does not work, because the existing system of admission to Ukrainian universities, in general, the further, the more limits the possibility of school graduates to do that, so from year to year the number of Ukrainian school graduates, who go abroad to study, is growing, because it is much easier to realize their desire to study there.

For 5-7\% GDP growth, the Ukrainian economy needs an additional 5 million workers and about 2-3 million small businessmen. Given the current trends in the outflow of Ukrainians abroad, it will not be possible to maintain the positive dynamics of economic growth, and to achieve indicators of 7\% GDP growth annually - even more so. In addition, taking into account other demographic factors, in 2025 we can expect a complete collapse of the social security system, because one working Ukrainian will have three retirees (Radchuk, 2019). It will become difficult to finance national expenditures, such as pensions and infrastructure support, if more and more Ukrainians will work and pay taxes abroad instead of at home.

At present, if one working Ukrainian generates about \$8.5 thousand of GDP in Ukraine per year, then when migrating from Ukraine at the level of about 300 thousand people, the country's losses per year of GDP are $\$ 2.55$ billion/year. If we add to this the lost money spent on the preparation of human capital, and the lost potential return, and the funds of lost opportunities, then the total amount of losses can be several times greater.

\section{Prospects of migration, of its causes and consequences}

In the world, migration policy is quite dynamic and quite volatile. Generally, the trend toward liberalization has not been reversed, althou the post-1990 period is characterized by a decelerated liberalization and not by a reversal toward more restrictive policies (de Haas et al., 2018). The Ukrainian question is as follows: will the mass desire of Ukrainians to go to work change (in one direction or another), and can the Ukrainian government somehow influence on this process?

Prospects for the dynamics of the scale and structure of labor migration from Ukraine will depend on two main factors: 1 - from the internal migration policy and the general economic situation in the country, 2 - from the demand for labor in other countries and their openness to migrants.

Slowing down migration flows through quarantine is a temporary phenomenon, as the causes of migration do not disappear. In Ukraine, the scale of this slowdown is not so great. From mid-March to the end of May 2020, only about 500.000 migrants returned to Ukraine, mostly those with short-term contracts. Long-term migrants, many of whom have permanent residence permits and sometimes - the citizenship of recipient countries, are more likely to stay abroad. And receipts of private remittances to Ukraine from foreign migrants in MarchApril 2020 compared to the previous (record) year decreased by only 8\%: from $\$ 1.892$ billion to $\$ 1.748$ billion (Libanova, 2020). According to the Polish Embassy in Ukraine, during the coronawirus pandemic for the first month of quarantine from Poland to Ukraine returned 
about 5\% staying in Poland Ukrainians (Kresy.pl, 2020). That is - up to 300 thousand. According to a study conducted by the EWL employment agency and the East European Study of the University of Warsaw, Ukrainians in Poland are not afraid of the coronavirus, but of layoffs. 85\% earners from the East intend to stay in Poland and work (Trojan, 2020). That is, in fact, the lion's share of Ukrainians who worked abroad remained there. According to the All-Ukrainian Association of International Employment Companies, between three and five million Ukrainian citizens work abroad, and as a result of the pandemic, no more than $5-10 \%$ of them returned to Ukraine. During the period from January 1 to May 1, 1.87 million Ukrainians returned to Ukraine from Poland alone, and 1.99 million people went there to earn money, i.e., already in May in Poland there were 120 more Ukrainian workers than before pandemic (Drannik, 2020).

There are no exact statistics, because a large proportion of Ukrainians - according to the All-Ukrainian Association of International Employment Companies - about 60\% - work abroad illegally. For example, in Poland only 480 thousand Ukrainians as of the second half of 2019 paid contributions to the local social insurance fund, ie - worked legally. That is, it is not known for sure how many of the workers are left, what proportion of them still works or does not work and is in forced quarantine (Berdnik, 2020). Those who worked illegally, for example in Poland, were the first to lose their jobs and have no help from the state, and they are now returning to Ukraine.

The armed conflict in the east of Ukraine is unlikely to have any impact on the intensification of labor migration, not because there are signs of its end, but because by now those, who had to leave have long since left due to lack of work and housing and other normal conditions of productive existence. But the large-scale outflow of economically active population to countries with higher wages and better employment opportunities, better education, etc. will inevitably resume, as there are currently no grounds for another option in Ukraine.

According to the German Advisory Group, the pay gap between Ukraine and other European countries remains large. Although the average monthly salary in Ukraine has increased significantly - from \$192 in 2015 (the lowest figure during the economic crisis) to $\$ 326$ in 2018, it is still only about a quarter of the average salary in Poland or the Czech Republic and less than one tenth in Western or northern EU countries. According to CASE Ukraine, Ukraine ranks last place in Europe in terms of official earnings and had exchange places with Moldova (\$326 vs. \$375) (Dubrovskyj, 2018). The results of research commissioned by the Ministry of Foreign Affairs of Ukraine show that every third Ukrainian earner wants to stay in Poland permanently, and every sixth - to come regularly. After 9 months of stay in Poland, most of them no longer associate their future with Ukraine (Trojan, 2019a).

In addition, Ukraine has an extremely unfavorable and unstable investment climate, which significantly affects economic development. The overall level of convenience and comfort is unsatisfactory. There is little hope for a reduction in the cost of "expensive" loans to start a business. And, based on the realities and trends of their change, there is no reason to hope for the disappearance of such a natural desire as the desire to give their children a better life. 
On the other hand, the openness of EU countries to earners from Ukraine may increase: due to demographic change and an aging population, many countries will increasingly face labor shortages and may adjust their immigration policies accordingly. Europe will not be able to develop without Ukrainian labor, because the demographic situation there is not much better than in Ukraine. For example, according to Polish experts, if the crisis lasts until the end of the year, about two million Poles will lose their jobs, what is a lot for this country. And it is unlikely that Poles will go to work on these places where Ukrainians worked (Berdnik, 2020). According to the All-Ukrainian Association of International Employment Companies, Poland will probably be one of the most popular countries for labor migration of Ukrainians and the easiest option to go abroad for work or even stay there, as Poland has started a new phase of economic protection program and almost 670 thousand companies receive loans on very favorable terms (Journalist, 2020).

It should be taken into account that, according to the forecasts of the Institute of Demography and Social Research of the National Academy of Sciences of Ukraine, by 2031 the total population of Ukraine will decrease to 39.5 million people. The working-age population of Ukraine aged 20 to 64 will decrease by three million by 2030 . And there is also mortality and the negative birth rate (Tymoshenko, 2019). According to estimates submitted by UN DESA 2019, the total population projection for 2050 (medium variant) in Ukraine is 35.2 million (Migration Data Portal, 2019). And the matter is not just in high mortality and aging - Ukrainians continue to leave the country searching of a better life.

Unfortunately, many active, mobile, competitive Ukrainians determine their prospects of leaving not so much by their personal life as by the general low assessment of the situation in the country. This migratory factor is much more dangerous than a simple desire to earn. If whole families start leaving with a view to permanent residence, the transfers from earners will no longer fuel the domestic economy.

Therefore, to solve all these problems, you need to use non-standard methods. But above all, the question must be answered honestly as to whether, in the current circumstances, one can expect a sharp increase in wages and, as a result, the return of a significant number of Ukrainian citizens home. Obviously, we need to start with more pragmatic ways to revive the economy.

First, it is worth borrowing the experience of neighboring countries - if you can not please your citizens, invite strangers who want to work on the proposed wages.

Second, we need to make better use of our internal potential by helping people find employment.

Third - it is worth reducing the tax burden for small businesses, improving the conditions of business administration, reducing in loan rates, which together can motivate former earners to invest earned money in the economy.

It is also important to conclude pension agreements with countries where Ukrainian migrants work. It is essential to confirm at a high level the fundamental inadmissibility of the taxation of remittances, which are transfers within the family, and to finally exempt from customs duties the means of production imported by migrants for the development of their own business. 


\section{Conclusions}

Migration is not a problem that needs to be addressed in the direction of its elimination, but an objective reality that must be taken into account and which must be arranged with the appropriate benefit by regulating it. The mere fact of labor migration cannot indicate good or bad trends in the Ukrainian economy. However, labor migration does not occur for no reason and the increase in the number of people willing to earn abroad is a signal of significant economic imbalances in the domestic economy.

Characteristic features of international labor migration from Ukraine are that Ukrainian migrants are mainly from rural areas of western Ukraine and mostly - men (except for Italy) of young and middle age. They are dominated by people with vocational education, less represented are people with higher education. A significant proportion of migrants work in low-skilled jobs. Much of the migration from Ukraine is circular. However, the migration trend tends to increase the number of those who do not return to Ukraine - if there are no positive changes in the country's economy in the near future, the motivation to return for workers will decrease and in the long run people who went to work will be for Ukraine lost, which in the end naturally makes Ukraine poorer and threatens economic growth in the future. The situation is complicated by the lack of statistical collection systems and a clear governmental policy of labor migration.

Today, the main reasons for labor migration from Ukraine are - economic (search for a decent income) and educational (study abroad, get an education that is not available at home, improve their professional skills, learn a foreign language and then use their education at home or abroad). The situation in Ukraine convincingly shows that the economic factor, even under conditions of a real threat to human health and even a real mortal danger, is crucial in deciding on migration in search of better opportunities to earn money abroad.

Mass work of Ukrainians abroad, of course, has positive consequences for Ukraine: it is the inflow of currency (the amount of income from Ukrainian workers at home is growing every year and is already almost $10 \%$ in the dollar equivalent of Ukraine's GDP). Getting into the banking system, those money actually supports the stability of the national currency and the country's balance of payments), raising living standards of many groups and entire territories, reducing tensions in the labor market, assimilation of market consciousness, values and norms of a democratic society, etc.

In the long run, money laundering and migration of an increasingly family nature will exacerbate the demographic and economic problems in Ukraine. Significant remittances from abroad are already changing Ukraine's economy in the direction of slowing domestic growth and increasing its dependence on these funds from abroad, raising domestic prices and reducing the competitiveness of exports, which leads to a reduction in the number of jobs with highly skilled occupations and an increase in low-skilled jobs in the non-profit sector, and large inflows allow the government to respond less to the needs of society. The economy and authorituy are becoming "lazy". The negative consequences of migration from Ukraine should also include significant losses of highly skilled labor, specialists and 
scientists, a corresponding slowdown in the pace of scientific and technological progress; loss of qualification of migrants due to their performance of low-skilled work abroad, lack of deductions from the wages of illegal migrants to the social and pension fund; return of earners of retirement age; deterioration of family relations due to long-term absence of family members. In Ukraine, there is concern about the growing number of homeless children whose parents have gone to work

Objectively, it is possible to reduce the pace and reduce migration by improving the business climate and creating more favorable conditions not only for investors but also for every ordinary citizen. In order to control migration processes, the government should ensure necessary statistics collection in order to have up-to-date and comprehensive information on this important issue. Ukraine should try to adapt to netto migration and take advantage of it, mitigating the negative effects it causes. Ukraine needs economic growth and positive economic prospects to encourage people to stay and invest in their future in Ukraine. This will determine whether labor migration will remain a positive factor for Ukraine and Ukrainians, or whether it will become a negative spiral of depopulation and slow growth. In general, only monitoring and control of migration processes is not enough for their positive regulation. Wage increase is an intermediate element. It is necessary to begin with change of philosophy, the relation to work, to people, to workers. It is important to create such an economic system that focuses on the needs of ordinary workers, and not on the few holders of world wealth, and that would allow for a dignified life for everyone, also with a view to such resource management, that there will be enough of them on earth for future generations. In Ukraine, strengthening the national economy, promoting the development of science and technology, improving the legal system, improving living standards can turn it from an exporting country to an importing country of labor, which, of course, will cause a number of problems, but with tools to regulate immigration the state will be able to successfully overcome them.

\section{Funding}

The research and the article written on its results are made exclusively at the expense of the author. The cost of publishing of the article would be covered by the University of Rzeszów (Poland).

\section{Author contributions}

Conceiving of the study, the design and development of the analysis data, collection and analysis of data, data interpretation and writing of the whole article are the result of the work of the author himself.

\section{Disclosure statement}

The author declares no conflict of interest. 


\section{References}

Arango, J. (2000). Explaining migration: A critical view. International Social Science Journal, 52(165), 283-296. https://doi.org/10.1111/1468-2451.00259

Berdnik, M. (2020). The lion's share of Ukrainian earners remains abroad. https://www.dw.com/uk/chypovernutsia-zarobitchany-z-yes-v-ukrainu-cherez-koronavirus/a-52996263

Brzozowski, J. (2011). Economic theories of international migrations. Scientific Journals of the Cracow University of Economics, 855, 55-73.

Cabańska, J. (2018). Economic conditions of population migration in the European Union. In T. Czapiewski \& M. Smolaga (Eds.), European studies in Poland (pp. 153-171). Szczecin University.

Constant, A., \& Zimmermann, K. (2017). Challenged by migration: Europe's options (GLO Discussion Paper, 46). http://www.merit.unu.edu/publications/working-papers/abstract/?id=6448

Corbett, J. (2003). Ernest George Ravenstein, The Laws of Migration, 1885. CSISS Classics. https://escholarship.org/content/qt3018p230/qt3018p230.pdf?t=o0wt2w\%20\&v=lg

de Haas, H., Natter, K., \& Vezzoli, S. (2018). Growing restrictiveness or changing selection? The nature and evolution of migration policies. International Migration Review, 52(2), 324-367. https://doi.org/10.1111/imre.12288

Dmytruk, B., \& Chudayeva, I. (2018). Emigration processes in Ukraine: Motives, tendencies and effects on the country. Economika ta derzhava, 1, 4-10.

Doeringer, P., \& Piore, M. (1971). Internal labor markets and manpower analysis. Lexington.

Drannik, A. (2020). There has never been such a wave of migration. Events of the Week: Results and Facts, 24(471), 7.

Dubrovskyj, V. (2018). U rejtingu najbidnishih evropejs'kih derzhav Ukraïna pominjalasja miscjami z Moldovoju. https://case-ukraine.com.ua/expert-comments/najbidnishi-v-yevropi/

Garmash, V. (2018). 2 million Ukrainians work in Poland and 40 thousand Ukrainian students study. High Castle, 6-12, 8.

Hicks, J. (1932). The theory of wages. Macmillan.

International Monetary Fund. (2019). Ukraine: Request for stand-by arrangement and cancellation of arrangement under the extended fund facility-press release; Staff report and statement by the executive director for Ukraine (Report No 19/3). Washington, D.C.

International Organization for Migration. (2013). Migration in Ukraine: figures and facts. https://migrationdataportal.org/data? $\mathrm{cm} 49=804 \&$ focus=profile+\&i=flows abs_emig $1 \& \mathrm{t}=2013$

International Organization for Migration. (2018). World Migration Report 2018. The UN Migration Agency. https://worldmigrationreport.iom.int/2018

International Organization for Migration. (2020). World Migration Report 2020. The UN Migration Agency. https://issuu.com/unpublications/docs/world_migration_report_2020

Ivahnjuk, I. (2015). Development of migration theory under conditions of globalization. Part 1. The Age of Globalization: A Study of the contemporary global processes, 1(15), 36-51.

Ivantsyk, M. (2020). The impact of emigration processes on the modern economic situation in Ukraine (1991-2019). Scientific Herald of Uzhhorod University, Series History, 1(42), 109-117. https://doi.org/10.24144/2523-4498.1(42).2020.202431

Janicki, W. (2007). Review of the theory of population migration. Annales Universitatis Mariae CurieSkłodowska Lublin-Polonia, LXII, 14 Sectio B, 285-304.

Journalist. (2020). Expert: Ukraine will face a new wave of powerful labor migration. https://journalist. today/jekspert-ukrainu-ozhidaet-novaja-volna-moshhnoj-trudovoj-migracii/ 
Kacperska, E. (2016). International flows of labor. Scientific Journals of the Warsaw University of Life Sciences. Economics and Organization of Food Economy, 116, 21-36. https://doi.org/10.22630/EIOGZ.2016.116.43

Kaczmarczyk, P., \& Okólski, M. (2005). Migrations of high-class specialists in the context of Poland's membership in the European Union. Office of the Committee for European Integration, Warsaw.

Kapustianskaya, K. (2020). Prohibited earnings: Ukraine issued an ultimatum to European employers. https://www.segodnya.ua/economics/enews/zapreshchennye-zarabotki-ukraina-vydvinula-ultimatum-evro peyskim-rabotodatelyam-1438462.html

Kaźmierczak, K. (2020). The authorities finally provided data - Poland becomes an immigration state over 2 million foreigners in the country. https://kresy.pl/wydarzenia/regiony/polska-regiony/wladze-wreszcie-podaly-dane-polska-stala-sie-panstwem-imigracyjnym-ponad-2-miliony-cudzoziemco$\mathrm{w}-\mathrm{w}-\mathrm{kraju} /$

Kresy.pl. (2020). About 60\% of the work visas issued by the EU are Polish visas issued in Ukraine. https:// kresy.pl/wydarzenia/regiony/ukraina/ambasador-rp-60-wiz-pracowniczych-wydawanych-przez-ue-to-polskie-wizy-wydawane-na-ukrainie

Lewis, W. (1954). Economic development of unlimited supplies of labor. The Manchester School of Economic and Social Studies, 22(2), 139-191. https://doi.org/10.1111/j.1467-9957.1954.tb00021.x

Libanova, E. (2020). Labor migration from Ukraine: The impact of COVID-19. Mirror of the week. https://zn.ua/ukr/SOCIUM/trudova-migraciya-z-ukrayini-vpliv-covid-19-351189_.html

Migration Data Portal. (2019). UN DESA. Retrieved March 26, 2019, from https://migrationdataportal. org $/$ data?cm 49=804\&focus=profile+\&i=flows_abs_emig $1 \& \mathrm{t}=2013$

Migration Policy Institute. (2019). Migration Information Source. https://www.migrationpolicy.org/country-resource/ukraine

Nestorowicz, J., \& Anacka, M. (2019). Mind the gap? Quantifying interlinkages between two traditions in migration literature. International Migration Review, 53(1), 283-307. https://doi.org/10.1177/0197918318768557

Olsson, G. (1965). Distance and human interaction. A migration study. Geografiska Annaler: Series B, Human Geography, 47(1), 3-43. https://doi.org/10.1080/04353684.1965.11879282

O'Reilly, K. (2016). Migration theories: A critical overview. In A. Triandafyllidou (Ed.), Routledge handbook of immigration and refugee studies (pp. 25-33). Routledge.

Organisation for Economic Cooperation and Development. (2011). Tackling the policy challenges of migration: Regulation, integration, development. Development Centre studies. OECD Publishing.

Piche, V. (2013). Contemporary migration theories as reflected in their founding texts. Population, 68(1), 141-164.

Pieńkowski, J. (2020). The impact of labour migration on the Ukrainian economy (Discussion Paper 123). Luxembourg: Publications Office of the European Union.

Ponzel, M. (2020). The latter will turn off the light: What is the real scale of labor migration from Ukraine to the EU. https://protocol.ua/ru/ostanniy_vimkne_svitlo_yakimi_e_realni_masshtabi_trudovoi_ migratsii_z_ukraini_do_es/

Pyrozhok, O., \& Kornienko, J. (2018). Personnel hunger: How to stop the outflow of brains and hands from Ukraine. https://www.epravda.com.ua/publications/2018/03/26/635298/

Radchuk, O. (2018). When will earners return: Pros and cons of labor migration of Ukrainians. https:// www.slovoidilo.ua/2018/04/26/kolonka/aleksandr-radchuk/ekonomika/koly-povernutsya-zarobitchany-plyusy-ta-minusy-trudovoyi-mihracziyi-ukrayincziv

Radchuk, O. (2019). Return of labor migrants: What the state is doing wrong. https://www.slovoidilo. ua/2019/10/18/kolonka/aleksandr-radchuk/suspilstvo/povernennya-trudovyx-mihrantiv-ne-takrobyt-derzhava 
Ravenstein, E. (1885). The laws of migration. Journal of the Statistical Society of London, 48(2), 167-235. https://doi.org/10.2307/2979181

Slovo i dilo. (2018). To go or stay: How many Ukrainians want to live abroad. https://www.slovoidilo. ua/2018/03/16/infografika/suspilstvo/poyixaty-chy-zalyshytysya-skilky-ukrayincziv-xochut-zhytykordonom

Stark, O. (1991). The migration of labor. Basil Blackwell.

State Statistic Service of Ukraine. (2019). Migration movement of the population. SSSU. http://www. ukrstat.gov.ua/

Strelnikov, O. (2020). People's movement. The main figures on the emigration of Ukrainians over the past 20 years. https://nv.ua/ukr/ukraine/events/emigraciya-ukrajinciv-cikavi-fakti-i-cifri-statistika-oonnovini-ukrajini-50067302.html

Todaro, M. (1976). Internal migration in developing countries: A review of theory, evidence, methodology and research priorities. International Labor Office, Geneva.

Trojan, M. (2019a). More and more Ukrainians in higher management positions in Poland. https://kresy. pl/wydarzenia/coraz-wiecej-ukraincow-na-wyzszych-kierowniczych-stanowiskach-w-polsce/

Trojan, M. (2019b). Personnel service: The potential of Ukrainian immigration is exhausting, its character must be changed from temporary to permanent. https://kresy.pl/wydarzenia/personnel-service-wyczerpuje-sie-potencjal-ukrainskiej-imigracji-trzeba-zmienic-jej-charakter-z-tymczasowej-na-stala/

Trojan, M. (2020). Not a million but not full 150,000. Vice Premier greatly overestimate the number of Ukrainians leaved the Poland. https://kresy.pl/wydarzenia/nie-milion-a-niespelna-150-tys-wicepremier-mocno-przeszacowala-liczbe-ukraincow-ktorzy-wyjechali-z-polski/

Tymoshenko, D. (2019). Migration in Ukraine: How large is the problem? https://www.radiosvoboda. org/a/donbas-realii--mihracija/29826553.html

Tyshchuk, T. (2018). Great migration: Why no one in Ukraine knows how many of our citizens have gone abroad. https://voxukraine.org/uk/velika-migratsiya-chomu-nihto-v-ukrayini-ne-znaye-skilkinashih-gromadyan-viyihalo-za-kordon/

Vinokurov, Ya. (2019). Last year, workers transferred \$ 14 billion to Ukraine - the World Bank. https:// hromadske.ua/posts/minulogo-roku-zarobitchani-perekazali-v-ukrayinu-dollar14-mlrd-svitovijbank

Yashchenko, L. (2018). Poland and Germany for Ukrainian earners: Working conditions and living standards. https://fakty.com.ua/ua/ukraine/20181224-polshha-ta-nimechchyna-dlya-ukrayinskyjzarobitchan-umovy-roboty-ta-riven-zhyttya/

Yasinchuk, L. (2020). About productivity, money and insurmountable laziness. Express, 6-13, 2.

Zaha, D., \& Luke, M. (2020). The end is not in sight: Labor migration from Ukraine may slow down, but is likely to continue. https://voxukraine.org/uk/kintsya-krayu-ne-vidno-trudova-migratsiya-zukrayini-mozhe-spovilnitisya-prote-shvidshe-za-vse-trivatime/ 